\title{
LEPTIN AND ADIPONECTIN LEVELS OF ASTHMATIC IRAQI CHILDREN IN HILLA PROVINCE
}

\author{
AFRAH NAZAR AL MAMOORI*, MUFEEDJALIL EWADH, SUHAYR ESSA ALQAYSI
}

Department of Biochemistry, College of Medicine, University of Babylon, Iraq.Email: afrahnazar@yahoo.com

Received: 25 July 2017, Revised and Accepted: 11 October 2017

\section{ABSTRACT}

Objective: To assess the serum leptin and adiponectin in Iraqi children with asthma and compare it with healthy controls in Hilla province.

Methods: Leptin and adiponectin were measured in 100 children; 60 newly diagnosed with asthma and 40 non-asthmatic children with a comparable age and sex were enrolled in this study. Asthmatic children subdivided into two groups; 30 patients in each group (obese and non-obese). The age of patients and control ranged between 2 and 12 years. The study was conducted in the Department of Biochemistry, College of Medicine, University of Babylon, leptin and adiponectin were estimated by enzyme-linked immunoassay, enzyme-linked immunosorbent assay technique.

Results: An increase in leptin and decrease adiponectin levels in the obese group than in non-obese asthmatic and control groups, with significant difference $(\mathrm{p}<0.04)$ and $(\mathrm{p}<0.03)$, respectively.

Conclusion: Among obese asthmatic Iraqi children, increase and decrease levels of leptin and adiponectin, respectively, indicate the significant association between adipokines and obesity in asthma.

Keywords: Asthma, Obesity, Leptin, Adiponectin.

(C) 2017 The Authors. Published by Innovare Academic Sciences Pvt Ltd. This is an open access article under the CC BY license (http://creativecommons. org/licenses/by/4. 0/) DOI: http://dx.doi.org/10.22159/ajpcr.2017.v10i12.20394

\section{INTRODUCTION}

Asthma is the most common chronic lower respiratory disease in childhood throughout the world. Asthma most often starts early in life and has variable courses and unstable phenotypes which may progress or remit over time. The impact of asthma on the quality of life of patients as well as its cost is very high. Therefore, appropriate asthma management may have a major impact in the quality of life of the patients and their families, as well as on public health outcomes [1]. Currently, primary prevention is not possible.

Causes of asthma: All phenotypes of asthma are multifactorial disorders which are the result of a complex interplay between genetic and environmental factors. These factors are thought tolead to inflammatory and structural changes which cause asthma symptoms [2]. In addition to storing energy, adipose tissue exerts an extremely active endocrine function and produces a variety of factors which circulate and regulate systemic metabolism and inflammation $[3,4]$. Among these factors, adipokines are defined as those cytokines secreted by adipose tissue. Leptin, adiponectin, resistin, chemerin, apelin, visfatin, plasminogen activator inhibitor 1 , monocyte chemoattractant tumor necrosis factor alpha (TNF- $\alpha$ ), and interleukin 6 [5].

Adiponectin, a collagen-like plasma protein produced specifically by adipose tissue, is abundantly present in the circulation that is involved in the homeostatic control of circulating glucose and lipid levels [5]. Some but not all studies demonstrate that low serum total adiponectin concentrations are associated with a greater risk for asthma among women and peripubertal girls [6]. In children, the clinical studies about this issue are limited.

Leptin is mainly synthesized and secreted by adipocyte [7]. Effects of leptin on lung cells might also impact asthma. Bronchial epithelial cells express leptin receptors, and leptin causes epithelial cell proliferation and mucin protein expression [8-10]. Airway smooth muscle cells also express leptin receptors [11]. Some but not all studies indicate that high serum leptin concentrations are associated with greater odds for asthma prevalence, particularly among prepubertal boys, peripubertal and postpubertal girls, and women. The data suggest that this association may be more consistent in children than in adults.

\section{METHODS}

Ethical issues

The study was approved by the local ethics committee, all patients' parents take part in the study were already informed about the aim of the study, agreed, and signed consent.

\section{Date and duration}

The study was carried out on patients from Babylon Teaching Hospital for Gynecology and Pediatrics in Babylon Province, Hilla city, from February 2016 to May 2016.The practical side of the study was performed at the laboratory of Biochemistry Department at College of Medicine/University of Babylon.

\section{Study design}

The study design was a case-control study.

\section{Patients and control}

Sample size was calculated according to Daniel sample size formula equation. This study included 100 samples (60 patients divided into two groups [obese and non-obese], 40 apparently healthy control) the age of them from 2 to 12 years.

\section{Chemicals and methods}

A. Determination of serum leptin concentration by the DRG leptin enzyme-linked immunosorbent assay (ELISA) kit is a solid phase ELISAbased on the sandwich principle $[12,13]$.

B. Determination of serum adiponectin concentration by this ELISA kit uses sandwich-ELISA as the method. The micro-ELISA plate provided in this kit has been precoated with an antibody specific to ADP/Acrp30 [14] 


\section{RESULTS}

The total number of study groups was 100 child describe on three groups.

1. Obese children with asthma $(\mathrm{n}=30)$.

2. Non-obese children with asthma $(n=30)$.

3. Control children $(n=40)$.

Age

There was no significant difference in age (as mean) between control and asthmatic children (obese and non-obese) as demonstrated in Fig. 1.

\section{Gender}

Distribution of asthmatic children according to gender that shown in Fig. 2. The present study demonstrated that the incidence of asthma in male $(58.33 \%)$ is greater than females $(41.66 \%)$.

\section{Body mass index (BMI)}

Distribution of asthmatic children according to BMIthat shows in Fig. 3. The mean \pm standard error [SE] of BMI for control, non-obese and obese patients were $15.912 \pm 0.331,15.946 \pm 0.433$, and $20.078 \pm 0.349$,

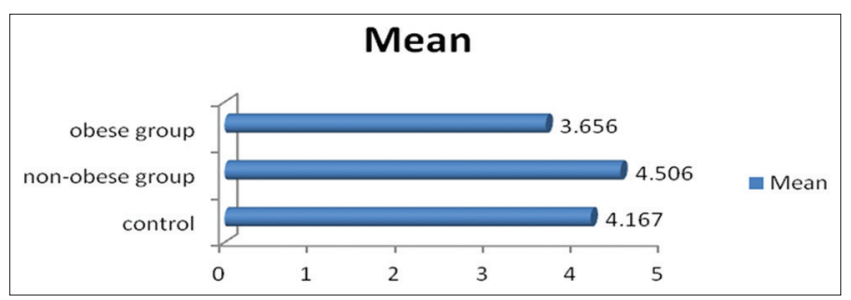

Fig. 1: Age studied groups

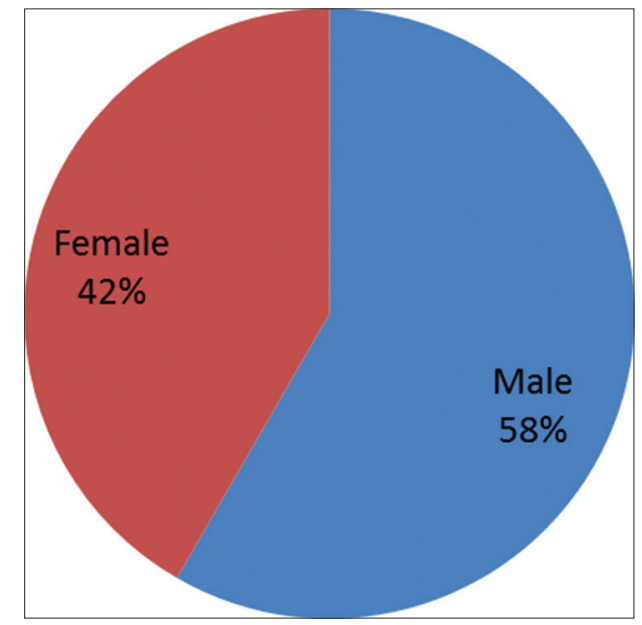

Fig. 2: Distribution of groups studied according to gender

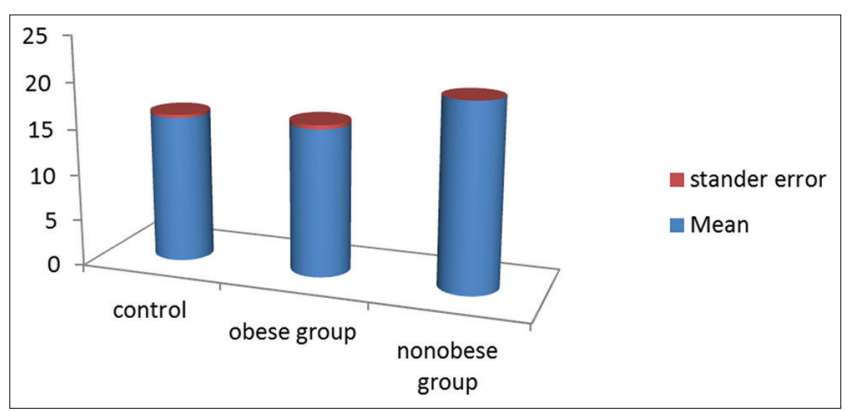

Fig. 3: Distribution of asthma patient according to body mass index respectively. The present result revealed that BMI was significantly $(p>0.01)$ greater in obese group when compared with non-obese patient or control, as shown in Fig. 3.

Serum leptin concentration as mean \pm SE of asthmatic children and control

As shown in Table 1, the mean \pm SEof leptin in asthmatic obese child was $6.801 \pm 1.090$ with a significant $(p<0.01)$ differences with both nonobese and control groups. While no significant $(p>0.05)$ differences of leptin between non-obese asthmatic patient $(1.650 \pm 0.385)$ and control $(2.856 \pm 0.749)$.

Serum adipokine concentration as mean \pm SEof asthmatic children and control

In this study, serum concentrations of adiponectin mean \pm standard deviation were significantly decrease $(p<0.01)$ in asthmatic (obese) children when compared with asthmatic (non-obese) and control group, as shown in Table 2 .

\section{DISCUSSION}

Asthma represents as a chronic inflammatory disorder of the airways and is associated with airways hyper-responsiveness that leads to recurrent episodes, often reversible, and widespread airflow obstruction within the lungs $[15,16]$. Body weight is one of the risk factors in asthma. Obesity is marked by low levels of systemic inflammation with elevated levels of inflammatory cytokines, adipokines, and acute phase proteins, including leptin, IL- 6 , TNF- $\alpha$, and C-reactive protein [17-19]. Indeed, obesity facilitates the development of metabolic disorders and cardiovascular diseases in addition to chronic diseases [20-22]. According to the statistics of this study, the mean age of patients who were diagnosed as asthmatic children (obese with non-obese) and control were $3.656,4.506$, and 4.167years, respectively. There was no significant difference in age (as mean) between control and patient groups as shown in Fig. 1. This age matching helps to eliminate the differences in parameters results that may originate due to the big variation in age. Many studies, Andrew et al. [23], Mahmood et al. [24], and Hazim et al. [25], are consistent with the fact that the majority of asthmatic children report disease onset before 6 years of age and depend on the same principle of age matching. On the other hand, this review demonstrates a slight male predominance with a 1.4:1 ratio. This finding is going with those of Tiran et al. [26] and Mahmood et al. [24]. Leptin, a hormone of adipose tissue, is associated with inflammation [27] and its levels have been shown to be higher in children with asthma than in those without [12]. The adipose tissue in obese subjects induces a systemic inflammatory state which produces a rise in the serum concentrations of proinflammatory adipokines, such as leptin; as proinflammatory and adiponectin, and as antiinflammatory. As body weight increases, more leptin is produced as revealed in our study population. As reviewed in Table 1, the highest leptin levels were observed in obese asthmatic children than those of obese asthmatic children and control with significant difference between them $(\mathrm{p}<0.01)$. These findings were consistent with some studies published recently [28] Guler et al. that found the same results. In fact, leptin was mainly secreted by adipocytes and target the cells directly, such as epithelial cells, nervous cells, and immune cells ( $\mathrm{T}$ helper), by expressing its receptor (LEPR) which lead to the first steps of pathological pathway of many inflammatory diseases [29]. Research Journal of pharmaceutical, biological, and chemical sciences reported that leptin in addition to its endocrine and metabolic function, it enhances the Th1 response, suppresses Th2 pathways, and can exert direct effects on CD4+ T-lymphocyte proliferation and macrophage phagocytosis. In obese children, leptin promotes IFN- $\gamma$ production in naive cells and memory T-cells but inhibits IL-4 synthesis in memory T-cells [5]. Furthermore, many inflammatory diseases may induce leptin releasing from adipose tissue or the lung which further increases the airway inflammation and hyper-reactivity [30-32]. This suggests that leptin plays a role as an inflammatory mediator in asthma, in support of previous reports of its inflammatory characteristics [33]. Adiponectin, 
Table 1: Leptin concentration in asthmatic children and control

\begin{tabular}{|c|c|c|c|c|}
\hline Parameters & Obese mean \pm SE $n=30$ & Non-obese mean \pm SE $n=30$ & Control mean \pm SE $n=40$ & $\mathbf{p}$ \\
\hline Leptin (ng/ml) & $6.801 \pm 1.090$ & $1.650 \pm 0.385$ & $2.856 \pm 0.749$ & $\begin{array}{l}<0.01^{*} \\
>0.05^{* *}\end{array}$ \\
\hline
\end{tabular}

SE: Stander error, N-number of study group. ${ }^{*}$ p value between obese and control, and between non-obese and obese. ${ }^{* *}$ p value between non-obese and control

Table 2: Adipokine concentration in asthmatic children and control

\begin{tabular}{|c|c|c|c|c|}
\hline Parameters & Obese mean \pm SE $n=30$ & Non-obese mean \pm SE $n=30$ & Control mean $\pm S E n=40$ & $\mathbf{p}$ \\
\hline Adiponectin (ng/ml) & $46.884 \pm 2.552$ & $52.145 \pm 0.706$ & $52.840 \pm 0.827$ & $\begin{array}{l}<0.01^{*} \\
>0.05^{* *}\end{array}$ \\
\hline
\end{tabular}

SE: Stander error, $\mathrm{N}$-number of study group. ${ }^{*}$ p value between obese and control, and between non-obese and obese. ${ }^{* *}$ p value between non-obese and control

similar to leptin, influences energy metabolism, but it has also anti- inflammatory effects [34]. Adiponectin is negatively associated with obesity because its concentration increases with weight loss [35]. The decrease of adiponectin in obesity may be related to the association between obesity and asthma [34-36], as allergen challenge leads to less airway responsiveness and inflammation in animal models with higher adiponectin levels [34]. Moreover, adiponectin inhibits the proliferation of cultured vascular smooth muscle cells [37]. If adiponectin was to have a similar influence on airway smooth muscle, the decrease in adiponectin in obese individuals could contribute to increased smooth muscle mass in asthmatic individuals [38]. Furthermore, the lower of adiponectin levels in obese compared with non-obese children with asthma and the lower adiponectin levels in non-obese children with asthma compared with controls in the present study support an anti-inflammatory role for this adipokine, as demonstrated in Table 2. These results agreed with [34-38].

\section{CONCLUSION}

Among obese asthmatic Iraqi children, increase and decrease levels of leptin and adiponectin, respectively, indicate the significant association between adipokines and obesity in asthma.

\section{REFERENCES}

1. Kupczyk M, Haahtela T, Cruz AA, Kuna P. Reduction of asthma burden is possible through National Asthma Plans. Allergy 2010;65:415-9.

2. Brand P, Wildhaber JH. Respiratory disorders, asthma. Forfar and Arneil's Textbook of Pediatrics. $7^{\text {th }}$ ed., Vol. 20. Edinburgh: Churchill Livingstone; 2008. p. 289

3. Maury E, Brichard SM. Adipokine dysregulation, adipose tissue inflammation and metabolic syndrome. Mol Cell Endocrinol 2010;314:1-16.

4. Fasshauer M, Blüher M. Adipokines in health and disease. Trends Pharmacol Sci 2015;36:461-70.

5. Jartti T, Saarikoski L, Jartti L, Lisinen I, Jula A, Huupponen R, et al. Obesity, adipokines and asthma. Allergy 2009;64:770-7.

6. Sood A, Shore SA. Adiponectin, leptin, and resistin in asthma: Basic mechanisms through population studies. J Allergy (Cairo)2013;2013:785835.

7. Ganji V, Kafai MR, McCarthy E. Serum leptinconcentration are not related to dietary patterns but are related to sex, age, body mass index, serum triacylglycerol, serum insulin, andplasma glucose in the US population. Nutr Metab 2009;6:1-3

8. Bruno A, Pace E, Chanez P, Gras D, Vachier I, Chiappara G, et al. Leptin and leptin receptor expression in asthma. J Allergy Clin Immunol 2009;124:230-7.

9. Tsuchiya T, Shimizu H, Horie T, Mori M. Expression of leptin receptor in lung: Leptin as a growth factor. Eur J Pharmacol 1999;365:273-9.

10. Woo HJ, Yoo WJ, Bae CH, Song SY, Kim YW, Park SY, et al. Leptin up-regulates MUC5B expression in human airway epithelial cells via mitogen-activated protein kinase pathway. Exp Lung Res 2010;36:262-9.

11. Nair P, Radford K, Fanat A, Janssen LJ, Peters-Golden M, Cox PG. The effects of leptin on airway smooth muscle responses. Am J Respir Cell Mol Biol 2008;39:475-81.

12. Considine RV, Sinha MK, Heiman ML, Kriauciunas A, Stephens TW,
Nyce MR, et al. Serum immunoreactive-leptin concentrations in normal weight and obese humans. N Engl J Med 1996;334:292-5.

13. Guillaume M, Björntorp P, Obesity in children, environmental and genetic aspects. Horm Metab Res 1996;28:573-81.

14. Elabscience Biotechnology Co. Ltd. Human LEP, (Leptin) ELISA Kit User Manual. Wuhan: Elabscience Biotechnology Co., Ltd.; ???.

15. Beuther DA, Weiss ST, Sutherland ER. Obesity and asthma. Am J Respir Crit Care Med 2006;174:112-9.

16. Shore SA. Obesity and asthma: Lessons from animal models. J Appl Physiol 2007;102:516-28.

17. Shore SA. Obesity and asthma: Implications for treatment. Curr Opin Pulm Med 2007;13:56-62.

18. Eff $\mathrm{AR}$, et al. Incidence of hypertension in asthma patients who treated with Beta-2 agonists bronchodilators. Int J Pharm Pharm Sci 2017;9:181-4.

19. Shore SA, Johnston RA. Obesity and asthma. Pharmacol Ther 2006;110:83-102.

20. Bollapragada MK, Shantaram M, Kumar RS, et al. Obesity: Development, epidemiology, factors affecting, quantity, health hazards, management and natural treatment-a review. Int $\mathrm{J}$ Pharm Pharm Sci 2017;9:12-26.

21. Singla P, Bardoloi A, Parkash AA. Metabolic effects of obesity: A review. World J Diabetes 2010;1:76-88.

22. Derdemezis CS, Voulgari PV, Drosos AA, Kiortsis DN. Obesity, adipose tissue and rheumatoid arthritis: Coincidence complex relationship? Clin Exp Rheumatol 2011;29:712-27.

23. Liu AH, Covar RA. Childhood asthma. Nelson Textbook of Pediatrics. $20^{\text {th }}$ ed., Vol. 144. Philadelphia, PA: Elsevier Health Sciences; 2015. p. 1095-1115.

24. Mahmood I. Growth Assessment in Asthmatic Children, A Thesis Submitted to Iraqi Council of Medical Specializations; 2009.

25. Hazim A. Risk Factors for the Occurrence of Childhood Asthma, A Thesis Submitted to Iraqi Council of Medical Specializations; 2005.

26. Kakarash TA, Al-Rabaty A. Zinc status in children with bronchial asthma. Iraqi Borad Med Specialization 2012;11:698-703.

27. Shimizu H, Shimomura Y, Hayashi R, Ohtani K, Sato N, Futawatari T, et al. Serum leptin concentration is associated with total body fat mass, but not abdominal fat distribution. Int J Obes 1997;21:536-41.

28. Guler N, Kirerleri E, Ones U, Tamay Z, Salmayenli N, Darendeliler F. Leptin: Does it have any role in childhood asthma? J Allergy Clin Immunol 2004;114:254-9.

29. Chiricozzi A, Raimondo A, Lembo S, Fausti F, Dini V, Costanzo A. Crosstalk between skin inflammation and adipose tissue-derived products: Pathogenic evidence linking psoriasis to increased adiposity. Expert Rev Clin Immunol 2016;12:1299-308.

30. Weiland SK, Bjorksten B, Brunekreef B, Cookson WO, von Mutius E, Strachan DP. International study protocol: International study of asthma and allergies in childhood (ISAAC): Rationale and methods. Eur Respir J 2004:24:406-12.

31. Sood A, Quails C, Seagrave J, Stidley C, Archibeque T, Berwick M, et al. Effect of specific allergen inhalation on serum adiponectin in human asthma. Chest 2009;135:287-94.

32. Stanford RH, Gilsenan AW, Ziemiecki R, Zhou X, Lincourt WR, Ortega H. Predictors of uncontrolled asthma inadult and pediatric patients: Analysis of the asthma control characteristics and prevalence survey studies (ACCESS). J Asthma 2010;47:257-62.

33. Jensen ME, Gibson PG, Collins CE, Wood LG. Airway and systemic inflammation in obese children with asthma. Eur Respir J 2013;24:1012-9. 
34. Meier U, Gressner AM. Endocrine regulation of energy metabolism: Review of pathobiochemical and clinical chemical aspects of leptin, ghrelin, adiponectin, and resistin. Clin Chem 2004;50:1511-25.

35. Faraj M, Havel PJ, Phélis S, Blank D, Sniderman AD, Cianflone K. Plasma acylation-stimulating protein, adiponectin, leptin, and ghrelin before and after weight loss induced by gastric bypass surgery in morbidly obese subjects. J Clin Endocrinol Metab 2003;88:1594-602.
36. Kattan M, Kumar R, Bloomberg GR, Mitchell HE, Calatroni A, Gergen PJ, et al. Asthma control, adiposity, and adipokines among inner-city adolescents. J Allergy Clin Immunol 2010;125:584-92.

37. Wang Y, Lam KS, Xu JY, Lu G, Xu LY, Cooper GJ, et al. Adiponectin inhibits cell proliferation by interacting with several growth factors in an oligomerization-dependent manner. J Biol Chem 2005;280:18341-7.

38. Shore SA, Terry RD, Flynt L, Xu A, Hug C. Adiponectin attenuates allergen-induced airway inflammation and hyper responsiveness in mice. J Allergy Clin Immunol 2006;118:389-95. 